\title{
Rancang Dan Bangun Game Edukasi Anak-Anak Berbasis Android Dengan Unity Menggunakan Metode Game Development Life Cycle
}

\author{
Raden Muhammad Mirza Prasetyo, Hadi Syaputra, Widya Cholil \& Siti Sauda \\ Fakultas Teknik Ilmu Komputer, Universitas Bina Darma \\ Email: mirzaprasetyoe860@gmail.com
}

\begin{abstract}
Technology is growing with the times, relentlessly and constantly moving forward to make new breakthroughs in all aspects of life. The IEA report in the Study of Reading Literacy states that the ability of elementary school children in Indonesia is very low. Of the 31 countries studied, Indonesia was ranked 30th. Based on the explanation of the background above, the researchers formulated the problem in this study, namely how to design and build an Android-based educational game with unity using the Game development life cycle (GDLC). This research was conducted in August 2021 in 9/10 Ulu Village, Plaju District, Palembang with a sample of 10 children. The research method uses Action Research and application development methods use GDLC. The results of testing the game system with blackbox that can be operated smoothly and for the results oftesting the feasibility of games with the results of $84.6 \%$ in the appropriate category, the results of development with Unity and GDLC succeeded in creating learning media based on android games quite well.
\end{abstract}

Keywords: Unity, Game Development Life Cycle (GDLC), Game Education, action research,blackbox

\section{Pendahuluan}

Teknologi semakin berkembang seiring zaman, tiada henti dan terus- menerus bergerak maju untuk membuat terobosan-terobosan baru di semua segikehidupan. Hal ini ditandai dengan adanya pengembangan teknologi di segala bidang, terutama untuk membantu mempermudah pekerjaan manusia. Selain itu, teknologi dalam bidang hiburan juga semakin berkembang pesat (Mustofa \& dkk, 2019). Terutama bidang Game digital sudah menjadi bagian dari aktivitas kehidupan manusia. Dukungan teknologi seluler dan komputer telah membawaGame digital sebagai salah satu bagian alat media pembelajaran atau pendidikan. Terkaitannya dengan pembelajaran, Game-Game digital tidak hanya mampu menghadirkan kegiatan yang bersifat immersive dan menyenangkan, melainkan kegiatan yang terkait dengan bidang pendidikan untuk mencapai tujuan tertentu. Memberikan manfaat sebagai alat pendidikan dan pembelajaran, Game digital telah mengalami transformasi menjadi Game edukasi digital. Game edukasi ini memberikan peluang-peluang terhadap pembelajar dalam hal mengembangkan keterampilan diri, pengetahuan dan sikap melalui prinsip-prinsip dan fitur yang digunakan di dalam Gameplay (Nikiforidou, 2018).

Perkembangan video Game sangatlah pesat, perkembangan grafis yang semakin canggih, serta semakin kayanya fitur-fitur yang tersedia dalam Game. Dibuktikan pendapatan video Game global yang terus meningkat dan diprediksi akan terus meningkat setiap tahunnya (Newzoo, 2018). Peningkatan ini terjadi di semua genre video Game baik yang besbasis desktop, mobile maupun console. Video Game juga merupakan salah satu hiburan

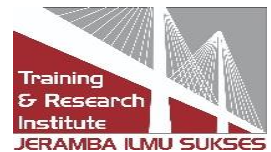


yang sangat digemari oleh semua kalangan usia. Mulai dari anak-anak hingga dewasa memainkan video Game (Mustofa \& dkk, 2019). Hasil survei menunjukkan data sebanyak $40 \%$ dari anak umur 2 hingga 8 tahun sudah menggunakan gadget dalam kehidupan sehari-hari. Namun disayangkan banyak Game yang dimainkan oleh anakanaksekarang ini adalah Game yang tidak memiliki fungsi pembelajaran sama sekali (Hartono \& dkk, 2015).

Perkembangan pembelajaran pada dunia pendidikan sangat diperlukan, melihat ketertarikan para siswa-siwi terhadap gadget lebih tinggi dibandingkan membaca buku pelajaran (Widyatmojo \& Muhtad, 2017). Pendidikan dasar yangmenjadi landasan bagi pengembangan pendidikan pada jenjang berikutnya,haruslah mampu berfungsi dengan sangat baik dalam mengembangkan potensi diri peserta didik dan juga sikap serta kemampuan dasar yang diperlukan peserta didik untuk hidup dalam masyarakat. Terutama persiapan untuk menghadapi perubahan-perubahan di masyarakat, baik dari segi ilmu pengetahuan, teknologi,sosial maupun budaya ditingkat lokal maupun global. Kemampuan dasar yang harus dimiliki peserta didik dan menjadi tujuan utama dalam pembelajaran di Sekolah Dasar (SD) adalah, kemampuan untuk membaca, menulis dan berhitung(Wirahayu \& dkk, 2014). Persoalan baca, tulis dan hitung menjadi isu penting karena laporan IEA dalam Study of Reading Literacy menyebutkan bahwa kemampuan anak sekolah dasar di Indonesia sangat rendah. Dari 31 negara yangditeliti, Indonesai menduduki peringkat ke-30, sedangkan peringkat tertinggi diduduki Finlandia dan beberapa negara maju termasuk Jepang. Fenomena rendahnya kemampuan membaca, menulis dan berhitung ini ibarat gunung es yang sedikit demi sedikit mencuat keluar, tetapi sejatinya banyak masyarakat Indonesia dari kalangan usia terutama anak-anak yang belum melek baca, tulis dan berhitung (Elly, 1992).

Pendidikan untuk anak usia dini sangatlah penting karena pencapaian perkembangan anak sangat pesat pada usia antara 0 - 6 tahun sehingga anak membutuhkan stimuluss yang tepat agar anak dapat berkembang sesuai dengantahapann perkembangannya. Educative Game berbasis aplikasi android untuk memfasilitasi keterampilan membaca anak usia 5 - 6 tahun agar meskipun anakbermain smartphone tetapi anak juga dapat mengembangkan keterampilan membacanya (Wijana \& dkk, 2014). Game edukasi unggul dalam beberapa aspek jika dibandingkan dengan metode pembelajaran konvensional. Salah satudari keunggulan yang signifikan adalah adanya animasi yang meningkatkan daya ingat sehingga anak dapat menyimpan materi pelajaran dalam waktu yanglebih lama dibandingkan dengan metode pengajaran konvensional (Donald, 2006). Sebagai salah satu insan mulia begerak dalam bidang pendidikan sudah selayaknya kita mengikuti perkembangan yang dimana kita harus dituntut untukdapat menggunakan, mengaplikasikan berbagai macam jenis teknologi modern yang berkembang terutama dalam hal pengembangan aplikasi guna berguna danmempermudah pekerjaan manusia. Dengan penggunaannya yang sangat mudah, tidak jarang teknologi modern pun digunakan oleh anak usia dini untuk sekedar menonton video-video dan bermain permainan yang menyenangkan bagi mereka(Febriani \& dkk, 2018).

Dari penjelasan latar belakang di atas, Salah satu pemanfaatan teknologi dalam pembelajaran adalah dengan memanfaatkan fungsi android. Pemanfaatan android sebagai media belajar sangat efektif dan efisien dimana dapat membuatmereka berfikir

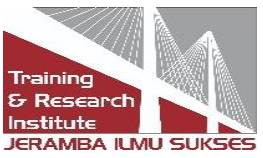


bahwa belajar adalah suatu kegiatan yang menyenangkan karenamereka dapat bermain sekaligus belajar sehingga mereka tidak mudah bosan dancepat memahami apa yang mereka pelajari. Dari penjelasan di atas yang sudah dijabarkan, penulis ingin merancang dan membuat Game edukasi untuk anak- anak usia dini ( 3 - 8 tahun) yang bisa dipelajari kapanpun dan dimanapun dengan smartphone yang dilengkapin visualisasi yang menarik. Maka penulis tertarik untuk mengajukan judul skripsi berjudul "RANCANG DAN BANGUN GAMEEDUKASI ANAK - ANAK BERBASIS ANDROID DENGAN UNITY MENGGUNAKAN METODE GAME DEVELOPMENT LIFE CYCLE”.

\section{Tinjauan Literatur}

Unity adalah sebuah program aplikasi pengembangan yang berbeda dariyang lain, dimana para developer menghabiskan waktunya lebih lama untuk membuat kode program. Unity lebih berfokus pada asset dari pada kode program, yang fokusnya ialah bagaimana menempatkan asset dalam ruang $3 \mathrm{~d}$ ataupun $2 \mathrm{~d}$ (Ratno, 2012). Unity adalah sebuah Game engine berbasis cross- platform, sehingga Unity digunakan untuk membuat Game yang bisa digunakanpada perangkat berbasis komputer, ponsel (Android), iPhone, Playstation, dan bahkan X-Box. Unity juga sebuah tool yang terintegrasi untuk membuat Game, arsitektur bangunan dan simulasi. juga bisa dipergunakan untuk membuat sebuah plugin tambahan seperti halnya dengan yaitu Unity Web Player (Blackman, 2011).

Unity adalah suatu program aplikasi yang berguna untuk mengembangkan Game multi platform dalam mendesain sehingga mudah digunakan. Unity penuh kombinasi dengan program aplikasi yang profesional. Editor pada Unity dibuat degan user interface yang tidak rumit (Horachek, 2014). Perizinan atau license dari Unity terbagi menjadi dua, yaitu Unity dan Unity Pro. Versi Unity tersedia dengan gratis, sedangkan versi Unity Pro berbayar. Versi Unity Pro mempunyai fitur bawaan seperti efek post processingdan render effect texture. Unity dan Unity Pro menyediakan dokumentasi untuk panduan dalam menggunakannya, contoh yaitu project, wiki, dukungan melaluiforum dan perbaruan kedepannya. Unity digunakan pada iPhone, iPod dan iPadoperating system yang mana iOS ada sebagai add-ons pada Unity editor yang telah ada lisensinya, dengan cara yang sama pada Android (Ardyanto \& dkk, 2017; Antoni, Fikari \& Akbar, 2018; Antoni \& Akbar, 2019; Antoni, Jie \& Abareshi, 2020; Antoni, Herdiansyah, Akbar \& Sumitro, 2021)

Game bukan suatu yang berfokus pada perencanaan system, seni, kreatifitas dan imajinasi, tetapi gabungan dari semua hal tersebut. Dengan begitudalam pembuatan video Game memerlukan tatacara khusus yang lebih spesifik. Sehingga munculah istilah (GDLC) Game Development Life Cycle. Game Development Life Cycle (GDLC) merupakan sebuah metode yang mengatasi pengembangan Game dimulai dari awal hingga akhir. Mulai dari tahap membuatide dan konsep tentang Game yang akan dibuat, sementara tahap akhir dari pengembangan Game adalah ketika Game dirilis. GDLC (Game Development Life Cycle) terdapat 6 tahapan yaitu (Ramadan \& Widyani, 2013) :

\section{Initiation}

Initiation ialah titik inisiasi proyek Game development. Awal pengembangan Game dimulai dari ide Game. Initiation merupakan sesi para pengembang berkumpul dan berdiskusi mengenai Game seperti apa yang mau dibuat. Proses pengembangan Game

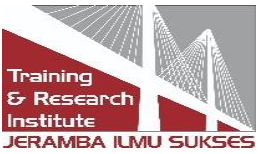


yang sangatserius dimulai dari proses iterative yaitu, Production Cycle.

2. Pre-production

Pre-production merupakan awal mula dari production cycle yang berkaitan dengan Game design. Pre-production ialah tahap yang penting sebelum proses pembuatan Game dimulai, karena pada tahapini melakukan perancangan Game, dan rencana produksi Game. Tahap ini terdiri dari Game design yaitu penyempurnaan konsep Game, dokumentasi dan prototyping, yakni pembuatan prototype dariGame.

\section{Production}

Game design dan prototype yang terdapat pada pre-production disempurnakan di production. Yang artinya, tahap ini berfokus pada rancangan Game design, concept art, dan aspek - aspek lainnya yangmenjadi suatu penyusun Game. Tahap ini berkaitan dengan programming, asset creation dan integration antara asset dan source code.

\section{Testing}

Testing ialah pengujian untuk prototype build. Pengujian ini dilakukan oleh internal developer team dalam melakukan usability test dan functionality test.

5. Beta

Setelah Game selesai dibuat, itu bukan berarti Game tersebut akan diterima oleh publik. Eksternal testing, atau istilah beta testing dilakukan untuk menguji Game dan untuk mendeteksi berbagai erroratau bug dan masalah yang didapat dari third party tester. Beta berada diluar production cycle, namun hasil dari testing ini memiliki potensi menyebabkan tim mengulangi production cycle lagi.

\section{Release}

Pada tahap ini dimana Game telah selesai dibuat dan telah lulusbeta testing yang bearti Game tersebut siap untuk dirilis ke publik. Release merupakan tahap dimana final build dari Game resmi dirilis.

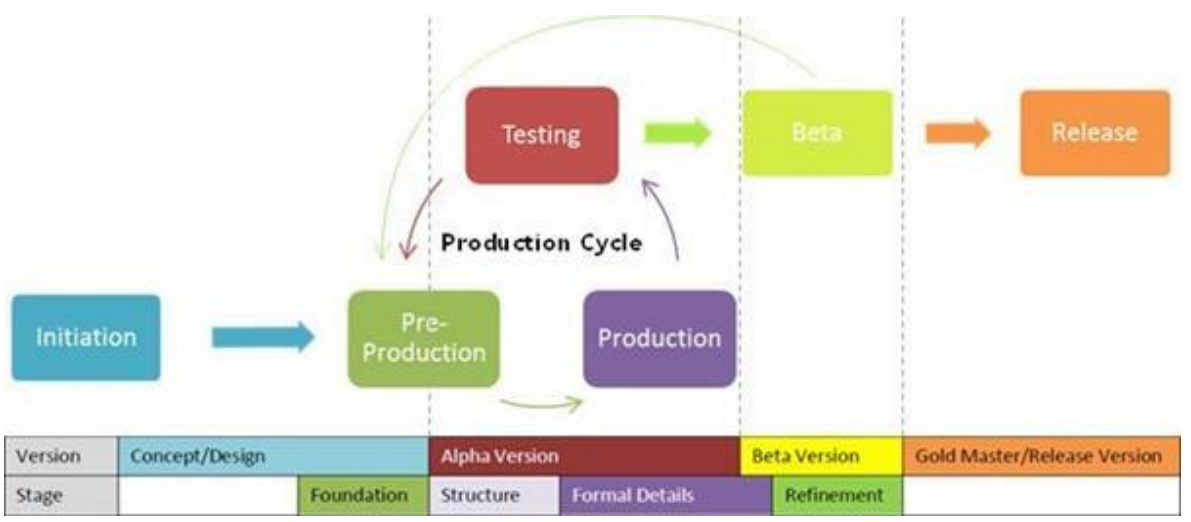

Gambar 1. Metodologi Game Development Life Cycle

\section{Metode Penelitian}

\subsection{Metode Pengembangan Aplikasi}

Game Development Life Cycle (GDLC) adalah salah satu metode yang digunakan dalam

Published by:

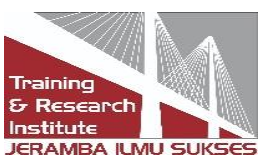


pengembangan Game dimulai dari tahap awal sampah tahap akhir. Diawali dengan tahap pembuatan ide dan konsep tentang Game apa yangakan dibuat, sedangkan di tahap akhir adalah saat Game dirilis. Dalam penelitianGame edukasi ini penulis menggunakan metode Game Development Life Cycle(GDLC) [9]. Tetapi pada penelitian ini hanya batas sampai tahap beta test tidak sampai tahap terakhir yaitu tahap release.

\subsection{Hasil Pengujian Menggunakan Blackbox}

Tabel 3.1 Hasil Pengujian Menggunakan Blackbox

\begin{tabular}{|c|c|c|c|c|c|}
\hline No & Nama $P$ & ujian & Bentuk Pengujian & $\begin{array}{l}\text { Hasil Yang Di } \\
\text { inginkan }\end{array}$ & $\begin{array}{c}\text { Hasil } \\
\text { Pengujian }\end{array}$ \\
\hline 1 & Loading & & Membuka Game & $\begin{array}{l}\text { Tampil Splash } \\
\text { Screen Logo Unity }\end{array}$ & Berhasil \\
\hline 2. & Pengujian & & $\begin{array}{ll}\text { Menekan } & \text { Tombol } \\
\text { PilihanMenu } & \end{array}$ & $\begin{array}{l}\text { Masuk ke menu } \\
\text { yang dipilih }\end{array}$ & Berhasil \\
\hline 3 & $\begin{array}{l}\text { Pengujian } \\
\text { Navigasi }\end{array}$ & Tombol & $\begin{array}{l}\text { Menekan Tombol } \\
\text { NavigasiKiri dan Kanan }\end{array}$ & $\begin{array}{l}\text { Berpindah ke List } \\
\text { Selanjut atau } \\
\text { sebelumnya }\end{array}$ & Berhasil \\
\hline 4 & $\begin{array}{l}\text { Pengujian } \\
\text { Reset }\end{array}$ & Tombol & Menekan Tombol Reset & $\begin{array}{l}\text { Mengulang Suara } \\
\text { Soal }\end{array}$ & Berhasil \\
\hline 5 & Pengujian & & $\begin{array}{l}\text { Nilai yang didapat } \\
\text { saatmenjawab soal }\end{array}$ & $\begin{array}{l}\text { Skor bertambah jika } \\
\text { jawaban benar }\end{array}$ & Berhasil \\
\hline 5 & $\begin{array}{l}\text { Pengujian } \\
\text { Jawab }\end{array}$ & Tombol & Menekan tombol jawab & $\begin{array}{l}\text { Mengkoreksi } \\
\text { jawaban benar atau } \\
\text { salah lalu masuk ke } \\
\text { soal berikutnya }\end{array}$ & Berhasil \\
\hline 6 & $\begin{array}{l}\text { Pengujian } \\
\text { Kembali }\end{array}$ & Tombol & Menekan tombol kembali & $\begin{array}{l}\text { Masuk ke menu } \\
\text { sebelumnya }\end{array}$ & Berhasil \\
\hline 7 & $\begin{array}{l}\text { Pengujian } \\
\text { keluar }\end{array}$ & Tombol & Menekan Tombol Keluar & $\begin{array}{l}\text { Keluar dari aplikasi } \\
\text { Game }\end{array}$ & Berhasil \\
\hline
\end{tabular}

\subsection{Pengujian Kelayakan Game}

\subsubsection{Populasi Dan Sampel}

Populasi adalah wilayah generalisasi yang terdiri atas objek atau subjek yang mempunyai kualitas dan karakteristik tertentu yang ditetapkan oleh penelitiuntuk dipelajari dan ditarik kesimpulannya. Sampel adalah bagian dari jumlah dan karakteristik yang dimiliki pada populasi (Fauzi, Dencik \& Asiati, 2019). Pada penelitianini yang menjadi populasi yaitu anak di Desa Kelurahan 9/10 Ulu Kecamatan Plaju Palembang. Dari populasi tersebut maka akan diambil beberapa sampel yaitu 10 orang anak. Aplikasi ini akan dimainkan oleh anak-anak denganbimbingan penulis.

\subsubsection{Teknik Pengambilan Sample}

Purposive sampling adalah teknik pengambilan sampel dengan menentukan kriteria-

Published by:

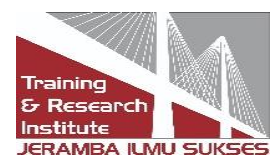


kriteria tertentu [10]. Pada penelitian ini, pengambilan sample menggunakan teknik purposive sampling, yaitu salah satu jenis teknik pengambilan sampel yang biasa digunakan dalam penelitian ilmiah.

Kriteria sampel dalam penelitian ini adalah :

1. Anak berusia $3-8$ tahun.

2. Bertempat tinggal di Desa Kelurahan 9/10 Ulu Kecamatan PlajuPalembang 3.3.3 Alat Pengumpulan Data

Skala likert dipergunakan untuk mengukur sikap, pendapat, dan persepsiterhadap inidvidu atau kelompok terkait dengan fenomena sosial yang sedang menjadi objek penelitian [10]. Alat pengumpulan data dingunakanoleh peneliti merupakan kuesioner jenis skala likert. Kuesioner ini bertujuan mendapatkan tanggapan anak tentang hasil Game. Kisikisi dapat dilihat dalam tabel 2.2 .

Tabel 3.2 Kisi-kisi Instrumen kelayakan Game

\begin{tabular}{|l|l|l|}
\hline No & \multicolumn{1}{|c|}{ Aspek } & \multicolumn{1}{c|}{ Indikator } \\
\hline \multirow{4}{*}{1.} & \multirow{3}{*}{ Media } & Kemenarikan Game \\
\cline { 3 - 4 } & & Kemudahan pengunaan Game \\
\cline { 3 - 4 } & & Kemenarikan tampilan Game \\
\cline { 3 - 4 } 2. & \multirow{2}{*}{ Pembahasan Mater } & Sederhana tampilan \\
\hline & & Kesederhanaan pembahasan \\
\cline { 3 - 4 } & & Fungsi dari pembahasan \\
\hline 3. & Kualitas Bahasa & Ketepatan pertanyaan \\
\hline 4. & Minat & Ketepatan contoh \\
\hline & & Ketepatan Bahasa \\
\hline
\end{tabular}

\subsubsection{Motode Pengumpulan Data}

Pada kuesioner terdapat beberapa pertanyaan yang berfungsi untuk mengetahui tanggapan anak mengenai Game yang telah dirancang. Kuesioner yang telah diisi responden kemudian dianalisis oleh peneliti untuk mendapatkan hasil.

\subsubsection{Teori Analisis Data}

Tanggapan yang diperoleh melalui kuesioner selanjutnya dianalisi oleh peneliti. Sistem yang digunakan untuk menganalisi data adalah deskriptif persentase. Hasil yang dianalisis merupakan tanggapan dari anak setelah merekamemainkan Game tersebut. Poin- poin dalam kuesioner, yaitu: 1) Sangat Tidak Setuju (STS) ; 2) Tidak Setuju (TS) ; 3) RaguRagu (R) ; 4) Setuju (S) ; dan 5) Sangat Setuju (SS) [10]. Tanggapan anak dianalisis dengan menggunakan rumus sebagai berikut [1] :

Ket : $\mathrm{P}=$ Persentase $(\%)$

Published by:

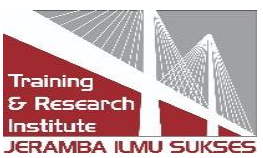




$$
\mathrm{P}=\frac{\text { Jumlah skor hasil pengumpulan data }}{\text { skor kriteria }} \times 100 \%
$$

Tolok ukur yang terdapat dalam angket terdapat dalam tabel 4.3 :

Tabel 3.3 Penilaian tanggapan peserta didik

\begin{tabular}{|l|l|c|}
\hline \multicolumn{1}{|c|}{ Persentase } & \multicolumn{1}{|c|}{ Keterangan } & Angka \\
\hline $81 \%-100 \%$ & Sangat setuju & 5 \\
\hline $61 \%-80 \%$ & Setuju & 4 \\
\hline $41 \%-60 \%$ & Ragu-ragu & 3 \\
\hline $21 \%-40 \%$ & Tidak setuju & 2 \\
\hline$<20 \%$ & Sangat tidak setuju & 1 \\
\hline
\end{tabular}

Tabel 3.4 Angket Respon Anak

\begin{tabular}{|c|c|c|c|c|c|c|}
\hline \multirow[b]{2}{*}{ No } & \multirow[b]{2}{*}{ Pernyataan } & \multicolumn{5}{|c|}{ Alternatif Pilihan } \\
\hline & & 1 & 2 & 3 & 4 & 5 \\
\hline 1. & $\begin{array}{l}\text { Game edukasi belajar membaca dan berhitung } \\
\text { berbasis android di desain sangat menarik } \\
\text { minatanak untuk mempelajarinya. }\end{array}$ & & & & & \\
\hline 2. & $\begin{array}{l}\text { Game edukasi belajar membaca dan } \\
\text { berhitung berbasis android di desain mudah } \\
\text { dipahami olehanak. }\end{array}$ & & & & & \\
\hline 3. & $\begin{array}{l}\text { Tampilan pada Game edukasi belajar membaca } \\
\text { dan berhitung berbasis android sangat } \\
\text { menarikminat anak untuk memainkannya. }\end{array}$ & & & & & \\
\hline 4. & $\begin{array}{l}\text { Game edukasi belajar membaca dan } \\
\text { berhitung berbasis android yang di desain } \\
\text { sederhana dan } \\
\text { tidak membingungkan anak } \\
\text { dalammemainkannya. }\end{array}$ & & & & & \\
\hline 5. & $\begin{array}{l}\text { Materi yang disajikan sangat mudah } \\
\text { untukdipelajari oleh anak. }\end{array}$ & & & & & \\
\hline 6. & $\begin{array}{l}\text { Materi yang disajikan sangat bermanfaat } \\
\text { untukanak saat belajar di sekolah, dirumah, } \\
\text { dimana } \\
\text { saja dan kapan saja. }\end{array}$ & & & & & \\
\hline 7. & $\begin{array}{l}\text { Quiz dan juga soal yang ditanyakan sangat } \\
\text { jelasdan tidak membingungkan anak. }\end{array}$ & & & & & \\
\hline 8. & $\begin{array}{l}\text { Soal yang disajikan sangat mudah dipahami } \\
\text { olehanak. }\end{array}$ & & & & & \\
\hline 9. & $\begin{array}{l}\text { Bahasa yang digunakan tepat sehingga anak } \\
\text { mudah memahaminya. }\end{array}$ & & & & & \\
\hline 10. & $\begin{array}{l}\text { Ingin tahu anak mendalami materi yang } \\
\text { diberikanbertambah. }\end{array}$ & & & & & \\
\hline 11. & $\begin{array}{l}\text { Anak lebih tertarik mempelajari materi } \\
\text { dengan adanya Game edukasi belajar } \\
\text { membaca dan } \\
\text { berhitung berbasis android. }\end{array}$ & & & & & \\
\hline
\end{tabular}

\section{Hasil dan Pembahasan}

\subsection{Hasil Respon Anak}

Berdasarkan hasil yang didapatkan dapat disimpulkan diketahui bahwa produk Game edukasi belajar membaca dan berhitung bebasis android, berhasilmenarik minat anak usia dini di Desa Kelurahan 9/10 Ulu Kecamatan Plaju Palembang. Hal ini berdasarkan hasil dari analisis tanggapan anak, yaitu $84,6 \%$ yang dapat diliat pada tabel hasil 4.6

Published by:

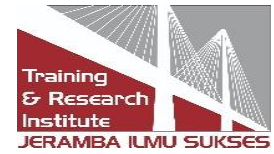


Berdasarkan poin persentase, nilai tersebut masuk dalam kategori sangat setuju (SS). Bedasarkan hal tersebut maka Game edukasi belajar membaca dan berhitung berbasis android layak digunakan untuk oleh anak-anak.

Tabel 4.1 Nama Anak

\begin{tabular}{|c|c|c|c|}
\hline No & $\begin{array}{c}\text { Nama } \\
\text { Anak }\end{array}$ & Umur & Jenis Kelamin \\
\hline 1. & Hazima & 8 & Perempuan \\
\hline 2. & Reva & 8 & Perempuan \\
\hline 3. & Cahya & 6 & Perempuan \\
\hline 4. & Putra & 5 & Laki-laki \\
\hline 5. & Yoga & 4 & Laki-laki \\
\hline 6. & Rati & 8 & Perempuan \\
\hline 7. & Arleta & 8 & Perempuan \\
\hline 8. & Tata & 8 & Perempuan \\
\hline 9. & Wanda & 8 & Perempuan \\
\hline 10. & Zaki & 8 & Laki-laki \\
\hline
\end{tabular}

Tabel 4.2 Hasil Responden Anak

\begin{tabular}{|c|c|c|c|c|c|c|c|c|c|c|c|c|c|c|}
\hline $\begin{array}{c}\text { Respon } \\
\text { den }\end{array}$ & $\begin{array}{c}\text { so } \\
\text { al } \\
\mathbf{1}\end{array}$ & $\begin{array}{c}\text { so } \\
\text { al } \\
\mathbf{2}\end{array}$ & $\begin{array}{c}\text { so } \\
\text { al } \\
\mathbf{3}\end{array}$ & $\begin{array}{c}\text { so } \\
\text { al } \\
\mathbf{4}\end{array}$ & $\begin{array}{c}\text { so } \\
\text { al } \\
\mathbf{5}\end{array}$ & $\begin{array}{c}\text { so } \\
\text { al } \\
\mathbf{6}\end{array}$ & $\begin{array}{c}\text { so } \\
\text { al } \\
\mathbf{7}\end{array}$ & $\begin{array}{c}\text { so } \\
\text { al } \\
\mathbf{8}\end{array}$ & $\begin{array}{c}\text { so } \\
\text { al } \\
\mathbf{9}\end{array}$ & $\begin{array}{c}\text { so } \\
\text { al } \\
\mathbf{1 0}\end{array}$ & $\begin{array}{c}\text { so } \\
\text { al } \\
\mathbf{1 1}\end{array}$ & $\begin{array}{c}\text { Tot } \\
\text { al }\end{array}$ & $\begin{array}{c}\text { Rat } \\
\text { a- } \\
\text { Rat } \\
\text { a }\end{array}$ & $\begin{array}{c}\text { Jumlah } \\
\text { Persent } \\
\text { ase }\end{array}$ \\
\hline 1 & 5 & 5 & 4 & 4 & 5 & 5 & 5 & 5 & 5 & 5 & 5 & 53 & 4.8 & 96.4 \\
\hline 2 & 5 & 5 & 5 & 4 & 4 & 5 & 5 & 4 & 5 & 5 & 5 & 52 & 4.7 & 94.5 \\
\hline 3 & 4 & 5 & 5 & 5 & 5 & 5 & 5 & 5 & 4 & 5 & 5 & 51 & 4.6 & 92.5 \\
\hline 4 & 5 & 4 & 5 & 5 & 4 & 5 & 5 & 5 & 5 & 5 & 5 & 52 & 4.7 & 94.5 \\
\hline 5 & 5 & 4 & 5 & 5 & 5 & 4 & 5 & 5 & 4 & 4 & 5 & 52 & 4.7 & 94.5 \\
\hline 6 & 5 & 5 & 5 & 5 & 5 & 4 & 4 & 5 & 5 & 5 & 5 & 53 & 4.8 & 96.4 \\
\hline 7 & 5 & 5 & 4 & 3 & 5 & 4 & 5 & 3 & 5 & 5 & 4 & 48 & 4.4 & 87.3 \\
\hline 8 & 5 & 4 & 4 & 4 & 5 & 5 & 5 & 5 & 4 & 5 & 4 & 48 & 4.4 & 87.3 \\
\hline 9 & 4 & 5 & 5 & 4 & 5 & 5 & 5 & 4 & 5 & 5 & 4 & 51 & 4.6 & 92.7 \\
\hline
\end{tabular}

Sebagai hasil pengujian kelayakan Game dan pengujian sistem Game, Game edukasi belajar membaca dan berhitung berbasis android memiliki kelebihan dan kekurangan. Kelebihan diantaranya :

a. Merupakan Game edukasi yang dapat digunakan sebagai pembelajaran secara mandiri maupun pembelajaran di sekolah yang dapat dilakukan dimanapun dan kapanpun.

b. Game edukasi belajar belajar membaca dan berhitung berbasis android dapat menarik minat anak-anak.

c. Materi yang disajikan singkat dan jelas sehingga mudah dipahami oleh anak-anak.

d. Quiz dan Game menjadi daya tarik tersendiri untuk anak-anak.

e. Tombol yang disediakan dalam Game mudah untuk dioperasikan oleh anak.

Selain kelebihan di atas, terdapat juga kelemahan Game edukasi belajar membaca dan berhitung berbasis android ini yaitu soal yang terdapat pada Gameterbatas dan belum

Published by:

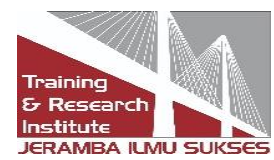


maksimal, dikarenakan materi perhitungan hanya sebatas penjumlahan dan pengurangan, serta fitur yang disajikan masih sedikit.

\section{Kesimpulan}

Berdasarkan analisis data yang sudah dilakukan maka dapat di tarikkesimpulan sebagai berikut :

1. Berdasarkan permasalahan yang ada dilatar belakang bahwa anak- anak di Indonesia belum melek baca, tulis dan berhitung. Dengan adanya teknologi yang semakin maju dengan pemikiran anak usia diniyang lebih suka bermain dan untuk menyeimbangkan pendidikan anakmaka diciptakannya game edukasi agar anak dapat bermain sambil belajar.

2. Game edukasi ini di buat dengan menggunakan software game engine yang bernama Unity.

3. Hasil pengembangan dengan Unity berhasil menciptakan media pembelajaran berbasis Game android dengan cukup baik.

4. Game edukasi belajar membaca dan berhitung disukai anak-anak sebagai media

5. pembelajaran berbasis Game yang bermanfaat dengan menggunakan Game Development Life Cycle (GDLC) sebagai metodepengembangan aplikasi dan Algoritma Penyelesaian Masalah dengan Flowchart.

6. Berdasarkan hasil pengujian sistem Game dengan blackbox yaitu dapat dioperasikan dengan lancar dan untuk hasil pengujian kelayakan Game kepada anak-anak dengan hasil 84,6\% kategori sangat setuju, Game edukasi belajar membaca dan berhitung berbasis android sehingga Game ini layak untuk digunakan oleh anak-anak.

7. Game edukasi belajar membaca dan berhitung sangat cocok untuk anak-anak karena memiliki tampilan penuh warna, terdapat animasi, serta suara atau musik sehingga Game tidak terkesan membosankan, Gameplay yang mudah, dan materi yang mudah dipahami.

8. Hasil dari game ini anak lebih memahami huruf dan angka yang ada di game ini, seperti mereka sedang bermain sambil menyebutkan lafal huruf dan angka sehingga anak jadi mudah memahami.

\section{Referensi}

Antoni, D., \& Akbar, M. (2019). E-supply chain management value concept for the palm oil industry. Jurnal Sistem Informasi, 15(2), 15-29.

Antoni, D., Fikari, D., \& Akbar, M. (2018). The readiness of palm oil industry in enterprise resource planning. Telkomnika, 16(6), 2692-2702.

Antoni, D., Herdiansyah, M. I., Akbar, M., \& Sumitro, A. (2021). Pengembangan Infrastruktur Jaringan Untuk Meningkatkan Pelayanan Publik di Kota Palembang. JURNAL MEDIA INFORMATIKA BUDIDARMA, 5(4), 1652-1659.

Antoni, D., Jie, F., \& Abareshi, A. (2020). Critical factors in information technology

Published by:

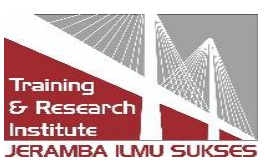


capability for enhancing firm's environmental performance: case of Indonesian ICT sector. International Journal of Agile Systems and Management, 13(2), 159-181.

Arikunto, S. (2010). Prosedur Penelitian Pendekatan Praktik. Jakarta: Rineka Cipta.

Donald, C. (2006). Game and e-learning. Sunderland: Caspian Learning.

Elly, W. B. (1992). How in the World Do Students Read, IEA Study of Reading Literacy. Hamburg: The International Association for the Evaluation of Education Achivement.

Fauzi, F., Dencik, A. B., \& Asiati, D. I. (2019). Metodologi Penelitian untuk manajemen dan akuntansi. Jakarta: Salemba Empat.

Febriani, A. S., \& dkk. (2018). PENGEMBANGAN EDUCATIVE GAME BERBASIS APLIKASI ANDROID UNTUK. Jurnal PAUD Agapedia, Vol.2 No. 2 , 188.

Hartono, L., \& dkk. (2015). Pembuatan Game Edukasi Pengenalan Flora Dan Fauna Indonesia. Jurnal Infra.

Mustofa, \& dkk. (2019). PENERAPAN BYL's GAME DEVELOPMENT LIFE CYCLE DALAMPERANCANGAN VIDEO GAME ORACLE FOR ANGEL. JURNAL ILMU PENGETAHUAN.

Newzoo. (2018). Global Games Market Report 2018. Newzoo Platform: The Ultimate Games Data Tool .

Nikiforidou, Z. (2018). Digital Games in the Early Childhood Classroom: Theoretical and Practical Considerations. Digital Childhoods, 253-265.

Ramadan, R., \& Widyani, Y. (2013). Game development life cycle guidelines. International Conference on Advanced Computer Science and Information Systems (ICACSIS).

Sugiyono. (2011). Metode Penelitian Kuantitatif, Kualitatif, dan R\&D. Bandung: CV. AFABETA.

Widyatmojo, G., \& Muhtad, A. (2017). Pengembangan multimedia pembelajaran interaktif berbentuk Game untuk menstimulasi aspek kognitif dan bahasa. JurnalInovasi Teknologi Pendidikan, 41-42.

Wijana, W. D., \& dkk. (2014). Kurikulum Pendidikan Anak Usia Dini.

Wirahayu, K. Y., \& dkk. (2014). Implementasi Pembelajaran Tematik Berbantuan Media Audio Visual Terhadap Peningkatan Kemampuan Calistung Siswa Kelas 1 SD Negeri 7 SESETAN. E-journal Program Pascasarjana Universitas Pendidikan Ganesha Program Studi Pendidikan Dasar.

\section{Copyrights}

Copyright for this article is retained by the author(s), with first publication rights granted to the journal.

This is an open-access article distributed under the terms and conditions of the Creative Commons Attribution license (http://creativecommons.org/licenses/by/4.0/)

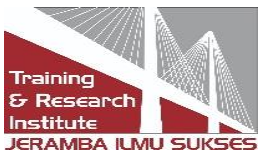

